\title{
MENINGKATKAN DISIPLIN GURU PADA WAKTU KEHADIRAN DISEKOLAH MELALUI PENERAPAN REWARD DAN PUNISHMENT DI SDN LIANG ANGGANG 1 KECAMATAN BATI-BATI KABUPATEN TANAH LAUT KALIMANTAN SELATAN
}

\author{
Isnaniah $^{1}$ \\ 1. SDN Liang Anggang \\ isnaniah888@gmail.com (082351244848)
}

\begin{abstract}
ABSTRAK
Penelitian ini bertujuan untuk mencari alternatif pemecahan masalah sebagai upaya untuk meningkatkan disiplin waktu kehadiran guru di sekolah melalui penerapan reward and punishment di SDN Liang Anggang 1 Kecamatan Bati-Bati Kabupaten Tanah Laut. Penelitian ini merupakan penelitian tindakan sekolah dengan desain yang diadaptasi dari model Kemmis dan Taggart, Penelitian ini dilakukan dalam dua siklus, setiap siklus mencakup empat tahap yaitu perencanaan, pelaksanaan, pengamatan dan refleksi. Subjek dalam penelitian ini adalah Guru PNS yang berjumlah 13 orang di SDN Liang Anggang 1 Kecamatan Bati-Bati Kabupaten Tanah Laut Tahun Ajaran 2017/2018. Tenik pengumpulan data yang digunakan adalah dengan observasi, lembar observasi digunakan untuk mengetahui disiplin guru dalam kehadiran di sekolah. Data yang terkumpul dianalisis dengan menghitung persentase guru yang hadir tepat waktu di sekolah. Hasil penelitian ini menunjukan bahwa penerapan reward and punishment di SDN Liang Anggang 1 Kecamatan Bati-Bati Kabupaten Tanah Laut efektif meningkatkan disiplin waktu kehadiran guru di sekolah. Berdasarkan hasil observasi data pada akhir siklus I yaitu 69,3\% guru hadir tepat waktu, kemudian dilanjutkan dengan siklus II dan mendapatkan hasil akhir yaitu 84,6\% guru hadir tepat waktu. Berdasarkan indikator yang telah ditetapkan bahwa keberhasilan tindakan ini adalah minimal $80 \%$ guru hadir tepat waktu, Maka pada siklus II telah memenuhi kriteria dan dapat ditarik kesimpulan bahwa tindakan yang dilaksanakan pada siklus II dinyatakan berhasil.
\end{abstract}

Kata Kunci: disiplin, reward, punishment

\section{PENDAHULUAN}

\section{A. Latar Belakang Masalah}

Guru adalah teladan bagi peserta didiknya, setidaknya itulah makna tersirat dari Undang-Undang Guru dan Dosen nomor 14 Tahun 2005 pasal 1 ayat 1. Secara langsung maupun tidak langsung siswa akan belajar dari pengamatan dan kebiasaan yang dilihatnya setiap hari. Bagi anak, sekolah menjadi tempat belajar kedua setelah lingkungan keluarga. Sebagian besar waktu anak akan dihabiskan di sekolah, maka selayaknya seorang guru menjadi teladan yang baik.

Berdasarkan peraturan dari pemerintah pusat dan instansi Sekolah Dasar, sudah menjadi keharusan bagi para guru untuk mentaati peraturan sesuai dengan Undang-Undang Guru dan Dosen nomor 14 tahun 2005 bab IV pasal 20. Seorang guru harus bertanggung jawab secara penuh dan profesional pada kewajibannya, 
termasuk di dalamnya adalah ketepatan waktu kedatangan dalam bekerja. Seorang guru merupakan pendidik profesional dengan tugas utama mendidik, mengajar, membimbing, mengarahkan, melatih, menilai, dan mengevaluasi peserta didik pada pendidikan anak usia dini jalur pendidikan formal, pendidikan dasar, dan pendidikan menengah.

Tata tertib sekolah biasanya disusun untuk siswa maupun guru dan karyawan. Pemerintah melalui Permendiknas No. 19 Tahun 2007 menjelaskan bahwa tata tertib sekolah/ madrasah ditetapkan oleh kepala sekolah/ madrasah melalui rapat dewan pendidik dengan mempertimbangkan masukan komite sekolah/ madrasah, dan peserta didik. Tata tertib yang disusun sudah disepakati bersama untuk selanjutnya dapat dijalankan oleh seluruh warga sekolah. Dalam tata tertib disertai dengan punishment (hukuman) bagi yang melanggar. Namun kenyataanya punishment tersebut hanya berlaku bagi siswa saja. Berbeda halnya dengan guru dan karyawan, keberadaan punishment hanya sebatas formalitas.

Kurang maksimalnya disiplin dikalangan guru yang cukup memprihatinkan adalah perihal waktu kedatangan guru di sekolah. Sebagai seorang guru yang profesional, wajib melaksanakan tugas dan kewajibannya. Termasuk kewajibannya untuk mentaati peraturan atau tata tertib yang berlaku di sekolah. Kedisiplinan guru dalam melaksanakan tugas merupakan suatu hal yang belum dapat diselesaikan permasalahannya secara maksimal terutama jam masuk sekolah di sekolah-sekolah yang berada di pedesaan. Faktor jarak dan lokasi sekolah menjadi beberapa alasan keterlambatan. Keterlambatan guru masuk ke sekolah menggambarkan belum terbentuknya sikap guru yang berkualitas dan profesional.

Permasalahan mengenai disiplin terjadi pada guru di Sekolah Dasar Negeri Liang Anggang 1 Kecamatan Bati-Bati Kabupaten Tanah Laut. Berdasarkan hasil pengamatan tentang waktu kedatangan guru di SDN Liang Anggang 1 selama satu minggu terlihat bahwa guru SDN Liang Anggang 1 memiliki tingkat keterlambatan antara $61 \%$ sampai $84 \%$ dalam waktu satu minggu. Terpenuhinya kebutuhan secara finansial sebagai hak yang harus diterima sebagai pegawai negeri tidak sejalan dengan kewajiban yang harus dipenuhi guru dalam hal waktu kedatangan guru ke sekolah. Meskipun tidak seluruhnya datang terlambat namun rata-rata masih di atas $50 \%$ guru masih mendominasi keterlambatan.

Kondisi demikian apabila terus dibiarkan akan berdampak buruk terhadap kualitas pembelajaran dan karakter siswa, yakni siswa akan meniru gurunya yang kurang disiplin. Mengingat pentingnya disiplin bagi guru maka masalah keterlambatan kehadiran seperti yang telah dijelaskan sebelumnya perlu diatasi.

Ada beberapa penelitian terdahulu yang terbukti berhasil mengatasi permasalahan keterlambatan kehadiran guru yakni dengan menerapkan reward and punishment. Reward artinya ganjaran hadiah, penghargaan atau imbalan. Dalam konsep manajemen, reward merupakan salah satu alat untuk peningkatan motivasi para pegawai. Metode ini bisa meng-asosiasi-kan perbuatan dan kelakuan seseorang dengan perasaan bahagia, senang, dan biasanya akan membuat mereka melakukan suatu perbuatan yang baik secara berulang-ulang. Selain motivasi, reward juga bertujuan agar seseorang menjadi giat lagi usahanya untuk memperbaiki atau meningkatkan prestasi yang telah dapat dicapainya. Sementara punishment diartikan sebagai hukuman atau sanksi. 
Reward merupakan bentuk reinforcement yang positif, maka punishment sebagai bentuk reinforcement yang negatif, tetapi kalau diberikan secara tepat dan bijak bisa menjadi alat motivasi. Tujuan dari metode ini adalah menimbulkan rasa tidak senang pada sesuatu supaya mereka jangan membuat sesuatu yang tidak baik. Jadi, hukuman yang dilakukan mesti bersifat pedagogies, yaitu untuk memperbaiki dan mendidik ke arah yang lebih baik.

Berdasarkan uraian diatas, penulis tertarik untuk melakukan penelitian tindakan sekolah dengan judul : "Upaya Meningkatkan Disiplin Guru dalam Waktu Kehadiran di sekolah melalui penerapan Reward and Punishment di SDN Liang Anggang 1 Kecamatan Bati-Bati Kabupaten Tanah Laut".

\section{B. Rumusan Masalah}

Rumusan masalah dalam penelitian ini adalah :"Apakah penerapan Reward dan Punishment dapat meningkatkan disiplin guru dalam waktu kehadiran di sekolah?"

\section{Tujuan Peneltian}

Tujuan dari penelitian ini adalah ingin mencari alternatif pemecahan masalah sebagai upaya meningkatkan disiplin guru dalam waktu kehadiran di sekolah melalui penerapan Reward and Punishment.

\section{Manfaat Peneltian}

Penelitian ini diharapkan dapat bermanfaat bagi :

1. Kepala sekolah, yaitu wujud nyata kepala sekolah dalam memecahkan berbagai masalah disekolah melalui kegiatan penelitian.

2. Guru, yaitu menjadi motivasi guru dalam meningkatkan kedisiplinan dalam waktu kehadiran.

3. Sekolah, yaitu menjadi sumbangan dalam mewujudkan budaya sekolah yang dapat mendorong keberhasilan dan peningkatan mutu pembelajaran.

\section{A. Jenis Peneltian}

\section{METODE PENELITIAN}

Jenis penelitian yang digunakan adalah Penelitian Tindakan Sekolah (PTS). PTS merupakan suatu prosedur penelitian yang diadaptasi dari Penelitian Tindakan Kelas (PTK). Untuk lebih jelas bisa dilhat pada gambar 1 pada halaman selanjutnya.

Dari gambar tersebut dapat dilihat bahwa Penelitian Tindakan Sekolah (PTS) ini terdiri atas 4 tahap dalam tiap siklusnya, yaitu : 1) Perencanaan, 2) Pelaksanaan, 3) Pengamatan dan Evaluasi, 4) Refleksi. 


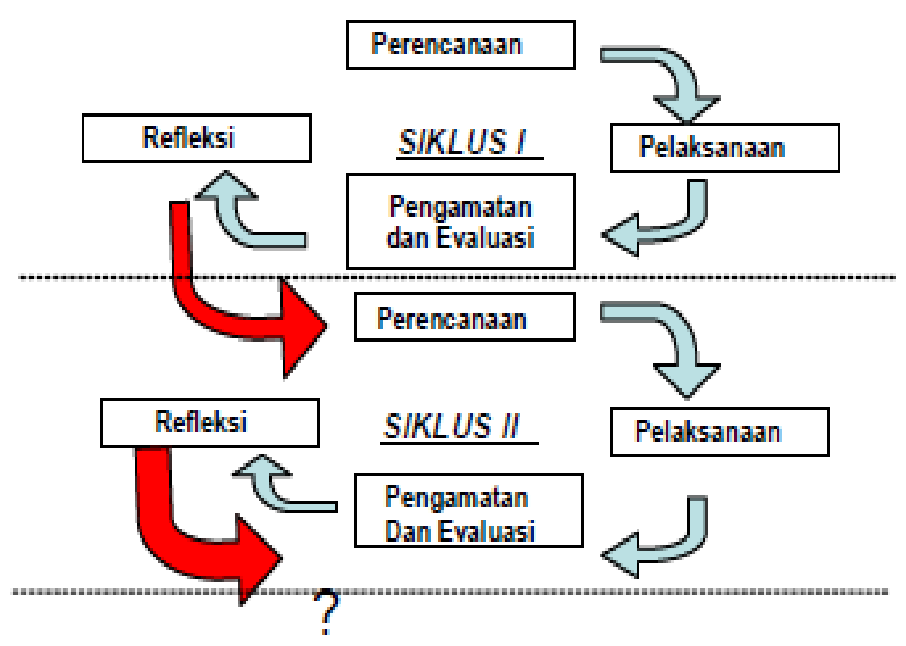

Gambar 1. Desain Peneltian Tindakan Sekolah (PTS) Adaptasi dari Kemmis dan Taggart

\section{B. Tempat dan Waktu Penelitian}

1. Lokasi Penelitian : SDN Liang Anggang 1 Kecamatan Bati-Bati Kabupaten Tanah Laut

2. Waktu Penelitian : 23 April 2018 s.d. 7 Mei 2018

\section{Teknik Pengumpulan Data}

Teknik pengumpulan data yang digunakan adalah observasi atau pengamatan dengan instrumen lembar observasi. Lembar observasi digunakan untuk mengumpulkan data waktu kehadiran guru di sekolah. Lembar observasi diberikan kepada observer yang telah ditugaskan untuk mengamati kehadiran guru di kelas. Hasil data yang diperoleh akan dianalisis setiap siklusnya.

\section{Indikator Keberhasilan}

Dalam penelitian ini yang menjadi indikator keberhasilan adalah apabila minimal guru yang hadir tepat waktu mencapai skor $80 \%$.

\section{A. Hasil}

\section{HASIL DAN PEMBAHASAN}

\section{Siklus I}

Siklus I terdiri atas empat tahap, yaitu : Perencanaan, Pelaksanaan, Pengamatan dan Evaluasi, dan Refleksi.

\section{Perencanaan}

Perencanaan adalah langkah awal yang dilakukan oleh penulis saat akan memulai tindakan. Agar perencanaan mudah dipahami dan dilaksanakan oleh penulis yang akan melakukan tindakan, maka penulis membuat rencana tindakan sebagai berikut :

a. Merumusan masalah yang akan dicari solusinya.

Dalam penelitian ini masalah yang akan dicari solusinya adalah disiplin guru dalam kehadiran di sekolah masih rendah. 
b. Merumusan tujuan penyelesaian masalah

Dalam penelitian ini penulis mengambil rencana untuk melakukan tindakan memberikan reward dan punishment kepada guru-guru untuk meningkatkan disiplin guru dalam kehadiran di sekolah.

c. Merumusan indikator keberhasilan

Indikator keberhasilan penerapan reward dan punishment dalam meningkatkan disiplin guru dalam kehadiran di sekolah ditetapkan sebesar $80 \%$, artinya tindakan ini dinyatakan berhasil bila $80 \%$ guru tidak terlambat hadir di sekolah.

d. Merumusan langkah- langkah kegiatan penyelesaian masalah

Langkah-langkah yang diambil penulis dalam melakukan tindakan antara lain adalah melakukan sosialisasi kepada para guru mengenai penelitian yang akan dilaksanakan, serta menyampaikan tujuan dari penerapan tindakan yang dilakukan oleh penulis.

Kepada para guru disampaikan mengenai penerapan Reward dan Punishment yang akan diterapkan dalam penelitian ini. Pada siklus pertama ini, akan dipampang/ditempel diruang guru, maupun diruang TU, peringkat nama-nama guru yang paling rendah tingkat keterlambatan sampai yang paling tinggi tingkat keterlambatannya.

e. Mengidentifikasi warga sekolah yang terlibat dalam melakukan tindakan.

Penulis melakukan identifikasi siapa saja yang dilibatkan dalam penelitian ini. Pihak-pihak yang dilibatkan dalam penelitian ini adalah : guru, guru piket, dan siswa.

f. Mengidentifikasi metode pengumpulan data yang akan digunakan.

Metode pengumpulan data yang diambil oleh penulis merupakan data kualitatif melalui observasi kepada guru dan wawancara kepada siswa mengenai kehadiran guru dikelas pada kegiatan belajar mengajar.

g. Penyusunan instrumen pengamatan dan evaluasi.

Dalam pengambilan data, penulis menggunakan instrumen berupa lembar observasi/pengamatan untuk guru, dan pedoman wawancara untuk siswa.

h. Mengidenifikasi fasilitas yang diperlukan.

Fasilitas atau alat bantu yang digunakan dalam penelitian ini antara lain : kertas (lembar pengamatan), alat tulis berupa balpoin, serta jam dinding yang ada disetiap kelas, serta rekap jumlah kehadiran dari setiap guru.

\section{Pelaksanaan}

Pelaksanaan penelitian tindakan sekolah ini dilaksanakan melalui beberapa kegiatan, antara lain:

a. Berkoordinasi dan menyebarkan lembar pengamatan kepada observer sebanyak 6 set sesuai dengan jumlah hari dalam siklus 1 yaitu 6 hari. Dalam lembar pengamatan tersebut, telah dibuat daftar guru dan diberi kolom waktu kehadiran di sekolah serta waktu pulang dari sekolah. Lembar pengamatan dapat dilihat pada lampiran.

b. Setiap hari setelah habis jam kerja guru dilakukan rekapitulasi hasil pengamatan, baik dari observer maupun dari penulis.

c. Kegiatan tersebut dilakukan terus setiap hari kepada setiap guru selama satu minggu (satu siklus). 
d. Memberi reward berupa pujian kepada Guru karena pada siklus I selalu hadir tepat waktu.

e. Memberi punishment berupa teguran kepada Guru karena beberapa kali datang terlambat lebih dari 5 menit pada siklus I.

\section{Pengamatan dan Evaluasi}

Pengamatan dan Evaluasi dilakukan oleh peneliti dengan menggunakan lembar observasi selama satu minggu (satu siklus), untuk semua guru yang berjumlah 13 orang. Selama pengamatan peneliti dibantu atau berkolaborasi dengan observer.

Data hasil pengamatan waktu kehadiran guru di sekolah pada Siklus I dapat dilihat pada tabel berikut :

Tabel 1. Data Waktu Kedatangan Guru di Sekolah Siklus I

\begin{tabular}{ccccc}
\hline Siklus I & Tepat waktu & $\begin{array}{c}\text { Terlambat } \\
\text { menit }\end{array}$ & $\begin{array}{c}\text { Terlambat } 5- \\
15 \text { menit }\end{array}$ & $\begin{array}{c}\text { Terlambat } \\
\text { lebih dari 15 } \\
\text { menit }\end{array}$ \\
\hline Jumlah Guru & 9 & 3 & 1 & 0 \\
\hline Persentase & $69,3 \%$ & $23 \%$ & $7,6 \%$ & $0 \%$ \\
\hline
\end{tabular}

Dapat dilihat dari tabel di atas, pada akhir siklus I terdapat 9 orang guru atau $69,3 \%$ yang datang di Sekolah tepat waktu, 3 orang guru atau $23 \%$ yang terlambat 5 menit, 1 orang guru atau 7,6\% yang terlambat 5 sampai 15 menit dan tidak ada satupun guru atau $0 \%$ yang terlambat lebih dari 15 menit.

Untuk lebih jelasnya dapat digambarkan pada diagram batang waktu kedatangan guru di bawah ini :

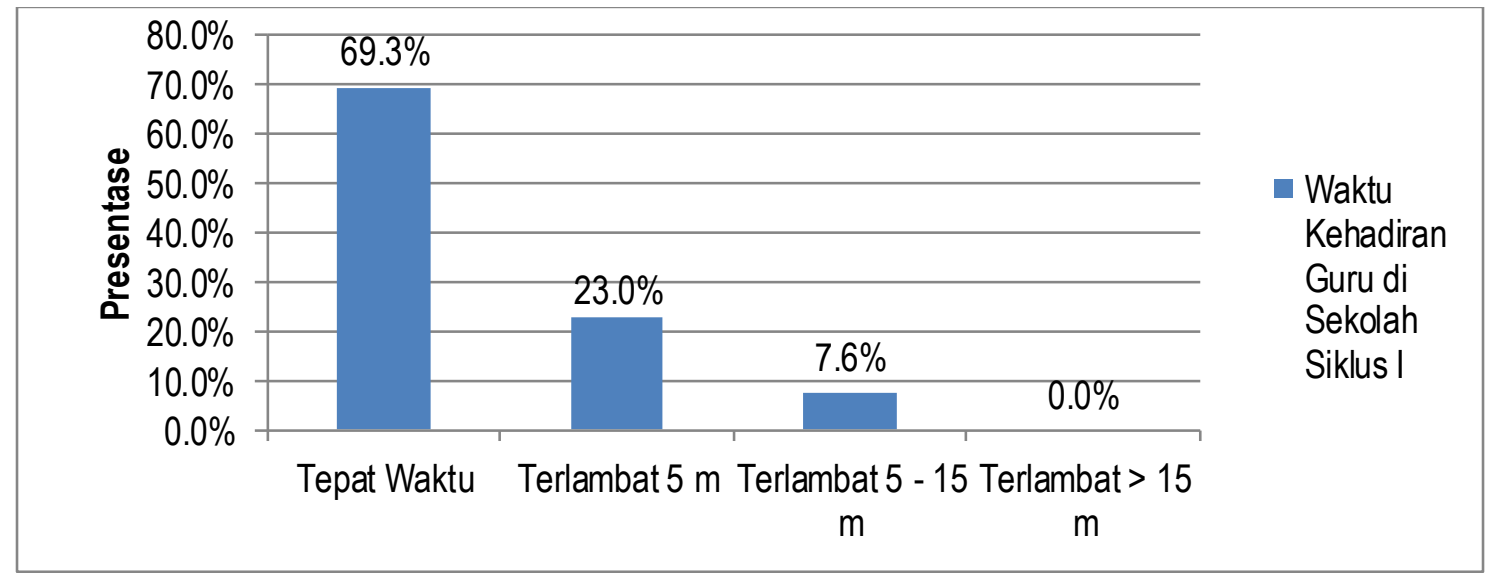

\section{Diagram 1. Waktu Kedatangan Guru di Sekolah Siklus I}

Dari data diatas dapat ditarik kesimpulan bahwa pada akhir siklus I tingkat disiplin kehadiran guru di sekolah yang tepat waktu adalah 9 orang atau masih diangka 69\%. Berdasarkan indikator yang telah ditetapkan bahwa keberhasilan tindakan ini adalah minimal $80 \%$ guru hadir tepat waktu, Maka pada siklus pertama ini masih belum memenuhi kriteria, jadi peneliti berkesimpulan harus diadakan tindakan lagi pada siklus berikutnya atau siklus kedua. 


\section{Refleksi}

Dari hasil kesimpulan tersebut perlu penerapan reward dan punishment yang lebih tegas lagi daripada siklus pertama. Yakni dalam pemberian reward yang sebelumnya pada Siklus I hanya memberi pujian, ditingkatkan dengan memberi penghormatan bahkan hadiah kepada guru yang hadir tepat waktu. Dan dalam pemberian punishment yang sebelumnya hanya berupa teguran ditingkatkan dengan member peringatan bahkan hukuman kepada guru yang terlambat.

\section{Siklus II}

Siklus II terdiri atas empat tahap, yaitu : Perencanaan, Pelaksanaan, Pengamatan dan Evaluasi, dan Refleksi.

\section{Perencanaan}

Secara umum perencanaan pada siklus II ini sama dengan siklus I hanya ada beberapa perbaikan sebagai berikut :

a. Merumusan masalah yang akan dicari solusinya.

Pada akhir siklus 1 tingkat disiplin kehadiran guru masih belum sesuai harapan, yakni masih dibawah indikator keberhasilan padahal penerapan reward dan punishment sudah dilakukan.

b. Merumusan langkah-langkah kegiatan penyelesaian masalah

Pemberikan reward dan punishment ditingkatan levelnya yaitu dalam pemberian reward yang sebelumnya hanya memberi pujian ditingkatkan dengan memberi penghormatan bahkan hadiah kepada guru yang hadir tepat waktu. Dan dalam pemberian punishment yang sebelumnya hanya berupa teguran ditingkatkan dengan memberi peringatan bahkan hukuman kepada guru yang terlambat.

\section{Pelaksanaan}

Pelaksanaan penelitian tindakan sekolah ini dilaksanakan melalui beberapa kegiatan, antara lain:

a. Berkoordinasi dan menyebarkan lembar pengamatan kepada observer sebanyak 6 set sesuai dengan jumlah hari dalam siklus II yaitu 6 hari. Dalam lembar pengamatan tersebut, telah dibuat daftar guru dan diberi kolom waktu kehadiran di sekolah serta waktu pulang dari sekolah. Lembar pengamatan dapat dilihat pada lampiran.

b. Setiap hari setelah habis jam kerja guru dilakukan rekapitulasi hasil pengamatan, baik dari observer maupun dari penulis.

c. Kegiatan tersebut dilakukan terus setiap hari kepada setiap guru selama satu minggu (satu siklus).

d. Memberi reward berupa penghormatan dengan memberi piagam dan hadiah kepada Guru karena pada siklus II selalu hadir tepat waktu.

e. Memberi punishment berupa peringatan kepada Guru karena beberapa kali datang terlambat lebih dari 5 menit pada siklus II.

\section{Pengamatan dan Evaluasi}

Data hasil pengamatan waktu kehadiran guru di sekolah pada Siklus II dapat dilihat pada tabel 2 pada halaman selanjutnya.

Dapat dilihat dari tabel 2 tersebut, pada akhir siklus II terdapat 11 orang guru atau 84,6\% yang datang di Sekolah tepat waktu, 2 orang guru atau 15,3\% yang terlambat 5 menit, dan tidak ada satupun guru atau $0 \%$ yang terlambat 5 sampai 15 menit dan yang terlambat lebih dari 15 menit 
Tabel 2. Data Waktu Kedatangan Guru di Sekolah Siklus II

\begin{tabular}{ccccc}
\hline Siklus I & Tepat waktu & $\begin{array}{c}\text { Werlambat } 5 \\
\text { menit }\end{array}$ & $\begin{array}{c}\text { Terlambat } 5- \\
15 \text { menit }\end{array}$ & $\begin{array}{c}\text { Terlambat } \\
\text { lebih dari 15 } \\
\text { menit }\end{array}$ \\
\hline Jumlah Guru & 11 & 2 & 0 & 0 \\
\hline Persentase & $84,6 \%$ & $15,3 \%$ & $0 \%$ & $0 \%$ \\
\hline
\end{tabular}

Untuk lebih jelasnya dapat digambarkan pada diagram batang waktu kedatangan guru di bawah ini :

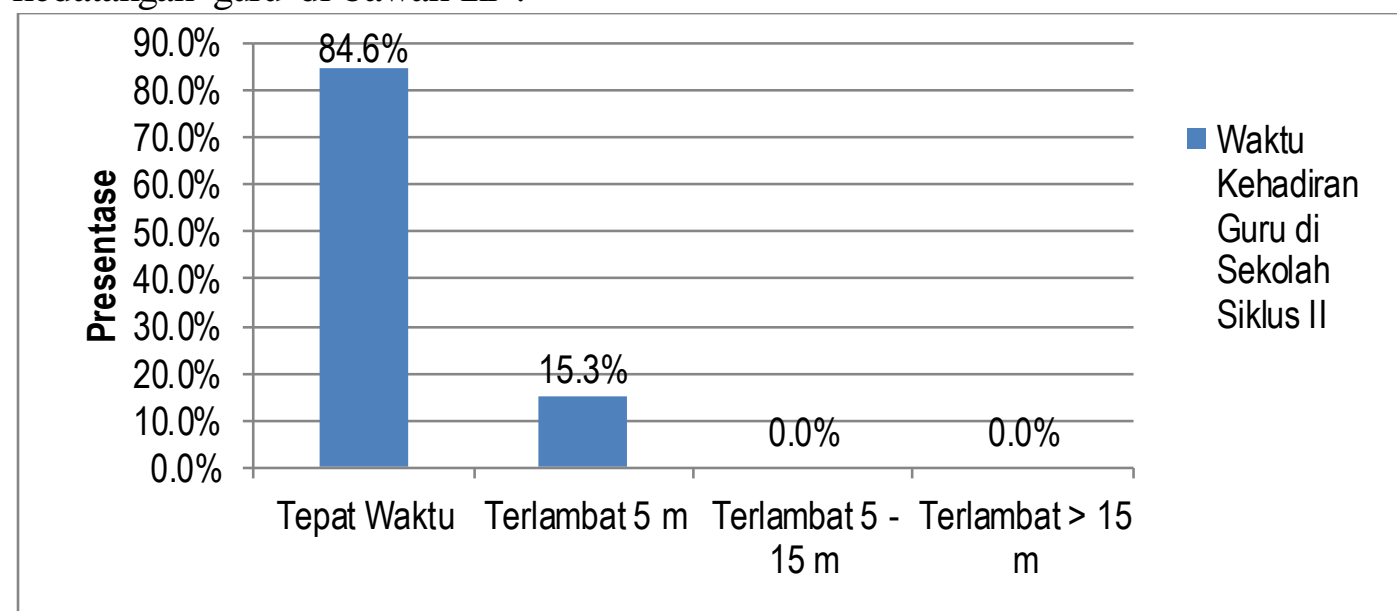

Diagram 2. Waktu Kedatangan Guru di Sekolah Siklus II

Dari data diatas dapat dilihat bahwa pada akhir siklus II tingkat disiplin kehadiran guru di sekolah yang tepat waktu adalah $84,6 \%$ dan yang terlambat 5 menit adalah $15,3 \%$. Hal tersebut menunjukan adanya peningkatan disiplin guru dari siklus I dengan siklus II dalam waktu kehadiran guru di sekolah.

\section{Refleksi}

Dari data yang dipaparkan diatas dapat ditarik kesimpulan bahwa pada akhir siklus II tingkat disiplin kehadiran guru di sekolah yang tepat waktu adalah $84,6 \%$. Berdasarkan indikator yang telah ditetapkan bahwa keberhasilan tindakan ini adalah minimal $80 \%$ guru hadir tepat waktu, Maka pada siklus kedua ini telah memenuhi kriteria dan dapat ditarik kesimpulan bahwa tindakan yang dilaksanakan pada siklus II dinyatakan berhasil. Sehingga tidak perlu menambah ke siklus berikutnya.

\section{B. Pembahasan}

Setelah data dianalisis diperoleh hasil akhir bahwa penerapan reward dan punishment di SDN Liang Anggang 1 efektif meningkatkan disiplin waktu kehadiran guru di sekolah.

Hasil penelitian tersebut sesuai dengan pendapat Hamalik (2009: 184) yang mengatakan bahwa reward memiliki tujuan untuk membangkitkan atau mengembangkan minat seseorang terhadap sesuatu. Pendapat lainnya dari Purwanto (2000: 182) yang juga mengatakan bahwa reward merupakan alat untuk mendidik seseorang supaya merasa senang karena perbuatan atau pekerjaannya mendapat penghargaan. 
Selain reward penelitian ini juga menggunakan tindakan punishment dan penggunakan tindakan tersebut terbukti berhasil meningkatkan disiplin kehadiran guru, hal tersebut sejalan dengan pendapat Baharuddin (2010:74) yang menyatakan bahwa hukuman adalah cara menghadirkan atau memberikan sebuah situasi yang ingin dihindari untuk menurunkan tingkah laku.

Hasil penelitian ini juga sejalan dengan hasil penelitian terdahulu seperti penelitian yang dilakukan oleh Sumarso, pada tahun 2010 yang menyimpulkan bahwa untuk meningkatkan disiplin guru dalam kehadiran dikelas pada kegiatan belajar mengajar dapat dilakukan dengan penerapan reward and punishment kepada guru. Penelitian lainnya dilakukan oleh Haryati, pada tahun ajaran 2016/2017 menunjukkan bahwa kinerja guru meningkat setelah dilakukan tindakan yang berupa penerapan reward and punishment selama dua siklus. Selanjutnya penelitian yang dilakukan Pristiyan, yang berjudul "Peningkatan Kedisiplinan Guru PNS Dalam Melaksanakan Tugas Melalui Penerapan Reward di Sekolah Dasar juga menunjukkan bahwa penerapan reward dapat meningkatkan kedisiplinan guru dalam hal kedatangan guru.

Berdasarkan dari pembahasan tersebut dapat disimpulkan bahwa penerapan reward dan punishment di sekolah efektif meningkatkan disiplin kehadiran guru. Hal tersebut sejalan dengan teori-teori yang ada dan sesuai dengan hasil penelitian terdahulu terkait dengan penerapan reward dan punishment di sekolah.

\section{A. Simpulan}

\section{SIMPULAN DAN SARAN}

Berdasarkan analisis data, dari penelitian ini dapat ditarik kesimpulan bahwa penerapan reward dan punishment berhasil meningkatkan disiplin waktu kehadiran guru di SDN Liang Anggang 1 Kecamatan Bati-Bati Kabupaten Tanah Laut.

Efektivitas penerapan reward dan punishment dalam meningkatkan disiplin waktu kehadiran guru bisa dilihat dari perbedaan yang signifikan antara kehadiran guru sebelum diberi tindakan dan sesudah diberi tindakan. Data yang diperoleh menunjukan bahwa setelah diadakan penerapan tindakan berupa reward dan punishment, guru yang hadir tepat waktu sebelum diberi tindakan adalah $35 \%$ dan setelah diberikan tindakan mencapai $84,6 \%$ angka tersebut sudah melebihi kriteria keberhasilan yang ditentukan.

\section{B. Saran}

Berdasarkan kesimpulan yang telah disampaikan, hasil penelitian ini diharapkan dapat memberikan sumbang pemikiran dalam dunia pendidikan, khususnya pada jenjang Sekolah Dasar. Beberapa saran sebagai usaha untuk lebih meningkatkan dunia pendidikan adalah sebagai berikut:

1. Bagi Kepala Sekolah, disarankan menerapkan reward dan punishment untuk meningkatkan disiplin guru dalam waktu kehadiran di sekolah.

2. Bagi Guru, dalam melaksanakan tugas untuk dapat meningkatkan disiplin kehadiran di sekolah sebagai bentuk pelayanan kepada peserta didik di sekolah. 


\section{DAFTAR RUJUKAN}

Ahmadi, A., \& Uhbiyati (1991) Ilmu Pendidikan. Jakarta: Rineka Cipta

Arikunto, S. (2012). Dasar- Dasar Evaluasi Pendidikan. Jakarta: PT. Bumi Aksara.

(2013). Psikologi Pendidikan Dalam Perspektif Baru. Yogjakarta : PT Purwa Atmaja Prawira

Daradjat, Z. (1991). Ilmu Pendidikan Islam. Jakarta : Bumi Aksara.

Depdiknas. (2005). Pembinaan Profesionalisme Tenaga pengajar (Pengembangan Profesionalisme Guru). Jakarta: Direktorat Jenderal Pendidikan dasar dan Menengah Direktorat Pendidikan Lanjutan Pertama Depdiknas.

Dimyati \& Mudjiono. (1999) Belajar dan Pembelajaran. Jakarta: PT. Rineka Cipta.

Dirjen Dikdasmen. (1996) Pengelolaan Sekolah di Sekolah Dasar. Jakarta: Depdikbud.

Djamarah, S, B,. (2008). Psikologi Belajar. Jakarta: Rineka Cipta

Haryati, L,. (2016). Upaya Meningkatkan Disiplin Guru dalam Kehadiran Mengajar Dikelas Melalui Penerapan Reward and Punishment. Jurnal Media Didaktika. Vol. 2 No.2.

Jalaluddin, R. (2004) Psikologi Agama Suatu Pengantar. Bandung: Mizan

Mulyasa, (2009) Standar Kompetensi dan Sertifikasi Guru. Bandung: Remaja Rosdakarya.

Pemerintah Republik Indonesia. (2005). Undang-Undang Republik Indonesia Nomor 14 Tahun 2005 Tentang: Guru Dan Dosen. Jakarta: Pemerintah Republik Indonesia.

Permadi, D. \& Arifin, D., (2010). Kepemimpinan Transformasional Kepala Sekolah dan Komite Sekolah. Bandung: Sarana Panca Karya Nusa.

Pristiyan, A, G,. (2016). Peningkatan Kedisiplinan Guru PNS Dalam Melaksanakan Tugas Melalui Penerapan Reward di SDN Mentisari Kecamatan Candiroto Kabupaten Temanggung. FKIP Universitas Kristen Satya Wacana Salatiga

Purwanto, M. N., (2000). Ilmu Pendidikan Teoritis dan Praktis, Bandung: Remaja Rosadakarya

Sardiman, A, M,. (2001). Interaksi dan Motivasi Belajar Mengajar. Jakarta: PT Raja Grafindo Persada.

Sindu, M,. dkk.,(2006) Panduan Lengkap Supervisi Diperkaya Perspektif Syariah. Jakarta: alex Media Komputindo

Soemarmo, D. (1998). Pedoman Pelaksanaan Disiplin Nasional dan Tata Tertib Sekolah. Jakarta: Mini Jaya Abadi.

Sumarso. (2010). Upaya Meningkatkan Disiplin Guru dalam Kehadiran Mengajar Dikelas Melalui Penerapan Reward and Punishment di SMP Negeri 3 Mandalawangi Kabupaten Pandeglang. Dinas Pendidikan Kabupaten Pandeglang. 
Meningkatkan Disiplin Guru pada Waktu Kehadiran di Sekolah Melalui Penerapan Reward dan Punishment di SDN Liang Anggang 1 Kecamatan Bati-Bati

Kabupaten Tanah Laut Kalimantan Selatan

Wibowo. (2001) Etika dan Moral Dalam Pembelajaran, Jakarta : Universitas Terbuka.

Yanuar, A., (2012) Jenis-Jenis Hukuman Edukatif untuk Anak SD. Yogyakarta: DIVA Press.

Yoesana, U. (2013). Hubungan antara Motivasi Kerja dengan Disiplin Kerja Pegawai. e-Jurnal Pemerintahan Integratif, ejournal.pin.or,id, 2013, 1 (1): 13-27. 